\title{
GAMBARAN STATUS GIZI BERDASARKAN LINGKAR LENGAN ATAS DAN INDEKS MASSA TUBUH PADA MAHASISWI FIKES UIKA BOGOR TAHUN 2019
}

\author{
Chyntia Nurul Adha ${ }^{1)}$, Tika Noor Prastia ${ }^{2)}$, Wina Rachmania ${ }^{3)}$ \\ ${ }^{1)}$ Konsentrasi Kesehatan Reproduksi dan Kesehatan Ibu Anak (KIA), Program Studi Kesehatan Masyarakat, Fakultas \\ Ilmu Kesehatan, Universitas Ibn Khaldun Bogor. \\ Email: chyntianuru130@gmail.com \\ ${ }^{2)}$ Konsentrasi Kesehatan Reproduksi dan Kesehatan Ibu Anak (KIA), Program Studi Kesehatan Masyarakat, Fakultas \\ Ilmu Kesehatan, Universitas Ibn Khaldun Bogor. \\ Email: tika@uika-bogor.ac.id \\ ${ }^{3)}$ Konsentrasi Kesehatan Reproduksi dan Kesehatan Ibu Anak (KIA), Program Studi Kesehatan Masyarakat, Fakultas \\ Ilmu Kesehatan, Universitas Ibn Khaldun Bogor. \\ Email: wina@uika-bogor.ac.id
}

\begin{abstract}
Abstrak
Status gizi adalah keadaan tubuh sebagai akibat konsumsi makanan dan penggunaan zat-zat gizi. Dampak jangka panjang dari masalah gizi pada WUS yang mengalami KEK adalah mempunyai risiko yang lebih besar untuk melahirkan bayi dengan BBLR, sedangkan dampak masalah gizi pada WUS yang mengalami obesitas adalah berisiko mengalami penyakit degeneratif. Tujuan dari penelitian ini adalah mengetahui gambaran status gizi berdasarkan Lingkar Lengan Atas dan Indeks Massa Tubuh pada mahasiwi Fikes UIKA Bogor. Metode penelitian adalah deskriptif kuantitatif dengan menggunakan metode cross sectional. Populasi penelitian adalah seluruh mahasiswi Fikes UIKA yang berjumlah 310 orang, dan sampel pada penelitian berjumlah 107 orang dengan menggunakan tekhnik Proportional Random Sampling. Instrumen penelitian menggunakan lembar pengukuran dan lembar panduan pengukuran antropometri. Analisa data menggunakan software pengolah data dengan uji univariat untuk melihat distribusi frekuensi variabel yang diteliti. Berdasarkan hasil penelitian menunjukan bahwa rata-rata responden berumur 20 tahun, 23,4\% mengalami KEK, 20,6\% mengalami status gizi kurang, dan 23,4\% mengalami status gizi lebih. Kesimpulan penelitian adalah mahasiswi dengan status gizi berat badan lebih cukup banyak dibandingkan mahasiswi dengan status gizi kurus, maka dari itu disarankan untuk menerapkan deteksi status gizi secara berkala kepada seluruh mahasiswa untuk mencegah gizi kurang dan gizi lebih.
\end{abstract}

Kata Kunci: Status Gizi, LiLA, IMT

\section{Pendahuluan}

Gizi merupakan salah satu penentu kualitas sumber daya manusia. Kekurangan gizi dapat menyebabkan gangguan pertumbuhan fisik dan perkembangan kecerdasan terganggu, menurunnya produktifitas kerja dan daya tahan tubuh yang berakibat meningkatnya angka kesakitan dan kematian. Kecukupan gizi sangat diperlukan oleh setiap individu sejak janin masih didalam kandungan, bayi, anak-anak, masa remaja, 
dewasa sampai usia lanjut (Depkes RI, 2001). Gizi mempunyai peran besar dalam daur kehidupan (Departemen Gizi dan Kesehatan Masyarakat, 2010).

Kurang Energi Kronis (KEK) adalah kondisi dimana tubuh kekurangan asupan energi dan protein yang berlangsung terus menerus (Almatsier, 2009). Kebutuhan energi pada orang dewasa $\pm 1.700-2.250$ Kalori, sedangkan kebutuhan protein pada usia dewasa adalah $50-60 \mathrm{~g}$ perhari atau berkisar $11 \%$ dari total masukan energi (Adriani \& Wirjatmadi, 2012). Gangguan kesehatan yang sering menyerang pada wanita usia subur adalah KEK (Arisman, 2009). WUS ialah wanita yang siap menjadi ibu, dimana kebutuhan gizi pada masa ini berbeda dengan masa anak-anak, remaja, ataupun lanjut usia (Puli, Thaha, \& Syam, 2014). Pada penelitian yang dilakukan Rahayu (2017) diperoleh bahwa ada hubungan yang signifikan antara umur dengan kejadian KEK (Rahayu, 2017).

Dampak jangka panjang dari masalah gizi pada WUS yang mengalami KEK adalah mempunyai risiko yang lebih besar untuk melahirkan bayi dengan BBLR. KEK pada wanita apabila tidak tertangani dengan baik dapat berkelanjutan saat hamil, yaitu selain dapat melahirkan bayi BBLR, juga akan membawa risiko kematian (Sofiyani, 2017). Untuk menanggulangi resiko melahirkan BBLR, sebelum kehamilan WUS sudah harus mempunyai gizi yang baik, misalnya dengan LiLA tidak kurang dari 23,5 cm. Apabila LiLA WUS sebelum hamil kurang dari angka ini, sebaiknya kehamilan ditunda sehingga tidak beresiko melahirkan BBLR (Adriani \& Wirjatmadi, 2012).

Menurut World Health Organization (WHO) 2012, permasalahan KEK telah dialami oleh hampir semua negara berkembang seperti Bangladesh, India, Indonesia, Myanmar, Srilanka dan Thailand dengan pravalensi KEK sebesar 15-47\%. Sementara itu, kondisi di Indonesia berdasarkan hasil Riset Kesehatan Dasar 2018
(Riskesdas), prevalensi risiko KEK pada WUS tidak hamil sebanyak 14,5\%. Menurut hasil Pemantauan Status Gizi (PSG) tahun 2017, status gizi penduduk dewasa ( > 18 tahun) berdasarkan Indeks Massa Tubuh (IMT) di Indonesia adalah kurus 5,0\%, normal $54,6 \%$, gemuk $14,6 \%$, dan obesitas $25,8 \%$.

Proporsi risiko KEK pada WUS (tidak hamil) berdasarkan umur interval 20-24 tahun mengalami kenaikan yang signifikan, yaitu dari 18,2\% tahun 2007 menjadi 23,3\% pada tahun 2018 (Riskesdas, 2018). Usia tersebut adalah usia mahasiswa pada umumnya, yakni usia peralihan dari remaja akhir menuju dewasa muda (Putri, 2016).

Berdasarkan hasil Riskesdas (2018), prevalensi risiko KEK pada WUS tidak hamil di Provinsi Jawa Barat sebanyak 14\%. Menurut hasil Pemantauan Status Gizi (PSG) tahun 2017, Prevalensi status gizi penduduk dewasa ( > 18 tahun) berdasarkan IMT di Jawa Barat adalah kurus 5,7\%, normal 49,2\%, gemuk $14,4 \%$, dan obesitas $30,7 \%$.

Berdasarkan data Dinkes Jabar (2016) Status gizi dewasa ( $>18$ tahun) dapat dilihat pada penduduk dewasa diatas 18 tahun adalah $11 \%$ kurus, $62,1 \%$ normal, $11,7 \%$ BB lebih dan $15,2 \%$ obesitas. Kota Bogor termasuk dalam prevalensi tertinggi peringkat ke 3 masalah status gizi yaitu $20,1 \%$.

Telah banyak dilakukan penelitian terkait LiLA dan IMT dengan status gizi mengenai KEK, namun prevalensi KEK pada WUS masih cukup tinggi. Penelitian mengenai gambaran status gizi berdasarkan LiLA dan IMT sebagai faktor KEK perlu dilakukan pada mahasiswi Fakultas Ilmu Kesehatan (FIKes) Universitas Ibn Khaldun (UIKA), karena belum pernah dilakukan penelitian terkait hal tersebut sehingga belum terdapat informasi yang memadai terkait status gizi mahasiswi Fikes UIKA.

Tujuan penelitian ini adalah untuk mengetahui gambaran status gizi berdasarkan lingkar lengan atas dan indeks massa tubuh 
pada mahasiswi FIKes UIKA Bogor tahun 2019.

\section{Metode}

Penelitian ini merupakan penelitian deskriptif dengan menggunakan pendekatan kuantitatif dengan desain penelitian Cross Sectional. Populasi dalam penelitian ini yaitu seluruh mahasiswi yang berada di Fakultas Ilmu Kesehatan Universitas Ibn Khaldun Bogor dengan jumlah populasi berjumlah 310 mahasiswi. Sampel didasarkan pada 2 kriteria yaitu kriteria inklusi, mahasiswi aktif dan mahasisiswi yang dalam keadaan sehat. Kriteria eksklusi, mahasiswi yang tidak bersedia untuk diteliti, contohnya sedang dalam keadaan sibuk, mahasiswi yang sedang tidak masuk pada saat penelitian, serta terdapat keadaan yang tidak memungkinkan

\section{Hasil}

\section{Gambaran Karakteristik Umur Mahasiswi}

Karakteristik umur memiliki peran penting dalam pengukuran status gizi seseorang. Berikut ini disajikan gambaran karakteristik umur pada sampel mahasiswi. Data gambaran tersebut dapat dilihat dalam tabel 1 dibawah ini.

Tabel 1 Distribusi Frekuensi Berdasarkan Umur Mahasiswi FIKes UIKA Tahun 2019

\begin{tabular}{crcc}
\hline Variabel & Mean & Median & $\begin{array}{c}\text { Minimal - } \\
\text { Maksimal }\end{array}$ \\
\hline Umur & 20 & 20 & $17-23$
\end{tabular}

Berdasarkan tabel 1 menunjukan bahwa rata - rata umur mahasiswi FIKes UIKA adalah 20 tahun dengan nilai tengah 20 tahun. Umur termuda berada pada umur 17 tahun sedangkan umur tertua ialah 23 tahun.

\section{Gambaran KEK}

Status gizi wanita dapat diketahui melalui pengukuran LiLA. Gambaran ukuran LiLA pada mahasiswi FIKes UIKA berdasarkan hasil analisis pada penelitian ini, untuk dilakukan penelitian, contohnya kondisi cacat fisik. Sampel yang telah digunakan, berjumlah 107 orang responden. Penelitian ini terdiri dari 4 variabel yaitu variabel lingkar lengan atas, berat badan, tinggi badan, dan IMT. Instrumen penelitian yang digunakan dalam penelitian ini berupa lembar panduan pengukuran antropometri dan lembar pengukuran untuk memperoleh biodata mahasiswi dan untuk mencatat hasil pengukuran antopometri LiLA, BB, dan TB. Analisis data dengan uji univariat dilakukan untuk melihat distribusi frekuensi variabel yang diteliti dan dengan uji crosstabs untuk mengetahui proporsi antar variabel.

dapat dilihat dalam tabel 2 dibawah ini.

Tabel 2 Distribusi Frekuensi Berdasarkan Pengukuran LiLA Mahasiswi FIKes UIKA Tahun 2019

\begin{tabular}{|c|c|c|}
\hline Variabel & n & $\%$ \\
\hline $\begin{array}{l}\text { Kekurangan Energi } \\
\text { Kronis }\end{array}$ & 25 & 23,4 \\
\hline Normal & 82 & 76,6 \\
\hline Total & 107 & 100,0 \\
\hline
\end{tabular}

Berdasarkan tabel 2 menunjukan bahwa mayoritas mahasiswi FIKes UIKA yang diukur berdasarkan LiLA berada pada klasifikasi normal yaitu $76,6 \%$, sedangkan yang mengalami KEK hanya sekitar 23,4\%.

\section{Gambaran BB}

Berdasarkan hasil analisis, diperoleh gambaran mengenai berat badan mahasiswi FIKes UIKA. Data tersebut dapat dilihat dalam tabel 3 dibawah ini. 
Tabel 3 Distribusi Frekuensi Berdasarkan Berat Badan Mahasiswi FIKes UIKA Tahun 2019

\begin{tabular}{cccc}
\hline Variabel & Mean & Median & $\begin{array}{c}\text { Minimal - } \\
\text { Maksimal }\end{array}$ \\
\hline Berat & & & \\
Badan & 52,93 & 51,9 & $34,9-92,5$ \\
$(\mathrm{~kg})$ & & & \\
\hline
\end{tabular}

Berdasarkan tabel 3 menunjukan bahwa rata-rata berat badan mahasiswi FIKes UIKA adalah $52,93 \mathrm{~kg}$ dengan nilai tengah $51,9 \mathrm{~kg}$. Berat Badan terendah berada pada $34,9 \mathrm{~kg}$, sedangkan berat badan terbesar ialah $92,5 \mathrm{~kg}$.

\section{Gambaran TB}

Berikut ini, disajikan data hasil analisis tinggi badan pada mahasiswi FIKes UIKA. Data tersebut dapat dilihat dalam tabel 3.4 dibawah ini.

Tabel 4 Distribusi Frekuensi Berdasarkan Tinggi Badan Mahasiswi FIKes UIKA Tahun 2019

\begin{tabular}{lccc}
\hline Variabel & Mean & Median & $\begin{array}{l}\text { Minimal - } \\
\text { Maksimal }\end{array}$ \\
\hline Tinggi & & & \\
Badan & $154,2^{*}$ & 154 & $143-167$ \\
$(\mathrm{~cm})$ & & & \\
\hline
\end{tabular}

Berdasarkan Tabel 4 menunjukan bahwa rata - rata mahasiswi FIKes UIKA memiliki tinggi badan $154,27 \mathrm{~cm}$ dengan nilai tengah $154 \mathrm{~cm}$. Mahasiswi dengan ukuran terendah memiliki tinggi badan $143 \mathrm{~cm}$ dan dan mahasiswi dengan ukuran tertinggi memiliki tinggi badan $167 \mathrm{~cm}$.

\section{Gambaran IMT}

IMT digunakan untuk mengetahui status gizi dewasa. Status gizi ditinjau berdasarkan ukuran BB dan TB yang dihitung dengan rumus IMT. Data IMT mahasiswi FIKes UIKA dapat dilihat dalam tabel 5 dibawah ini.

Tabel 5 Distribusi Frekuensi Berdasarkan IMT Mahasiswi FIKes UIKA Tahun 2019

\begin{tabular}{|c|c|c|}
\hline Variabel & $\mathbf{n}$ & $\%$ \\
\hline Kurus & 22 & 20,6 \\
\hline Normal & 60 & 56,1 \\
\hline Gemuk & 14 & 13,1 \\
\hline Obesitas & 11 & 10,3 \\
\hline Total & 107 & 100,0 \\
\hline \multicolumn{3}{|c|}{$\begin{array}{l}\text { Berdasarkan tabel } 5 \text { menunjukan bahu } \\
\text { g banyak mahasiswi FIKes UIKA yan } \\
\text { ur berdasarkan IMT memiliki status gi } \\
\text { hal yaitu } 56,1 \% \text {. Sedangkan persentas } \\
\text { asiswi yang memiliki status gizi gemu } \\
\text { obesitas lebih banyak (23,4\% } \\
\text { ndingkan dengan mahasiswi yan } \\
\text { hiliki status gizi kurus }(20,6 \%) \text {. }\end{array}$} \\
\hline
\end{tabular}




\section{Proporsi Antara Umur Dengan KEK}

Tabel 6 Crosstabs Berdasarkan Umur dengan KEK Pada Mahasisiswi FIKes UIKA Tahun 2019

\section{LiLA}

\section{Umur}

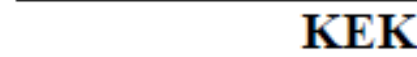

\section{Tidak KEK}

\begin{tabular}{ccccc} 
& $\mathbf{n}$ & $\mathbf{0}$ & $\mathbf{n}$ & $\mathbf{\%}$ \\
\hline 17 & 0 & $0,0 \%$ & 2 & $1,9 \%$ \\
18 & 4 & $3,7 \%$ & 11 & $10,3 \%$ \\
19 & 8 & $7,5 \%$ & 12 & $11,2 \%$ \\
20 & 4 & $3,7 \%$ & 23 & $21,5 \%$ \\
21 & 5 & $4,7 \%$ & 24 & $22,4 \%$ \\
22 & 4 & $3,7 \%$ & 9 & $8,4 \%$ \\
23 & 0 & $0,0 \%$ & 1 & $0,9 \%$ \\
\hline Total & $\mathbf{2 5}$ & $\mathbf{2 3 , 4 \%}$ & $\mathbf{8 2}$ & $\mathbf{7 6 , 6 \%}$
\end{tabular}

Berdasarkan tabel 6 menunjukan bahwa mengalami KEK lebih banyak berada pada Mahasiswi yang mengalami KEK berada pada umur 19 tahun, yaitu 8 mahasisiswi. umur 18 sampai 22 tahun, mahasiswi yang

\section{Proporsi Antara IMT Dengan KEK}

Tabel 7 Crosstabs Berdasarkan IMT Dengan KEK Pada Mahasiswi FIKes UIKA Tahun 2019

\begin{tabular}{|c|c|c|c|c|c|}
\hline \multirow{3}{*}{$\begin{array}{c}\text { Indeks Massa } \\
\text { Tubuh }\end{array}$} & \multicolumn{4}{|c|}{ LiLA } & \multirow{3}{*}{ Total } \\
\hline & \multicolumn{2}{|c|}{ KEK } & \multicolumn{2}{|c|}{ Tidak KEK } & \\
\hline & $\mathbf{N}$ & $\%$ & $\mathbf{n}$ & $\%$ & \\
\hline Kurus & 19 & $17,8 \%$ & 3 & $2,8 \%$ & 22 \\
\hline Normal & 6 & $5,6 \%$ & 54 & $50,5 \%$ & 60 \\
\hline Gemuk & 0 & $0,0 \%$ & 14 & 13,1 & 14 \\
\hline Obesitas & 0 & $0,0 \%$ & 11 & $10,3 \%$ & 11 \\
\hline Total & 25 & $23,4 \%$ & 82 & $76,6 \%$ & 107 \\
\hline $\begin{array}{l}\text { ahasiswi yang } \\
\text { bih besar berp }\end{array}$ & & & lib & $\begin{array}{l}\text { dengar } \\
\text { meng }\end{array}$ & $\begin{array}{l}\text { swi yang } \\
\text { EK yaitu }\end{array}$ \\
\hline
\end{tabular}




\section{Pembahasan}

\section{Gambaran Karakteristik Umur}

Menurut Arisman (2004) Obesitas lebih umum dijumpai pada wanita terutama pada saat remaja. Berdasarkan hasil penelitian menunjukan bahwa responden berada pada umur 17 sampai 23 tahun yang berarti masih termasuk kedalam kategori remaja. Hal ini sesuai dengan devinisi WHO (2007) yang menyebutkan bahwa batasan usia remaja adalah seseorang yang berusia 12 sampai 24 tahun. Umur tersebut juga tergolong dalam kategori WUS yaitu wanita yang memasuki usia antara 15 sampai 49 tahun tanpa memperhitungkan status perkawinannya (Depkes RI, 2011).

Berdasarkan hasil penelitian menunjukan bahwa rata - rata umur mahasiswi FIKes UIKA adalah 20 tahun dengan nilai tengah 20 tahun. Umur termuda berada pada umur 17 tahun sedangkan umur tertua ialah 23 tahun.

Hasil penelitian ini sejalan dengan penelitian yang dilakukan oleh Abaa, Polii dan Wowor (2017) yang menunjukan bahwa responden terbanyak berada pada usia 20 tahun yaitu 58,3\%. Hasil Penelitian yang dilakukan oleh Rahayu (2017) tentang Hubungan Umur dan Graviditas Dengan Kejadian KEK diperoleh bahwa ada hubungan yang signifikan antara umur dengan kejadian KEK.

\section{Gambaran KEK}

Kurang Energi Kronik (KEK) adalah kondisi di mana tubuh kekurangan asupan energi dan protein yang berlangsung terusmenerus (Almatsier, 2009). Kurang energi kronik menggambarkan "keadaan menetap" (steady state) di mana tubuh seseorang berada dalam keseimbangan energi antara asupan dan pengeluaran energi, meskipun berat badan rendah dan persediaan energi tubuh rendah (Mahirawati, 2014). mempunyai LiLA < 23,5 $\mathrm{cm}$ sebesar 23,4\% dan LiLA $\geq 23,5 \mathrm{~cm}$ sebesar 76,6\%. Hal tersebut menunjukan bahwa mayoritas mahasiswi yang diukur berdasarkan LiLA berada pada nilai normal atau tidak mengalami KEK. Namun persentase mahasiswi yang mengalami KEK cukup tinggi untuk mendapatkan perhatian.

Hasil penelitian ini sejalan dengan Aprianti (2017) yang menunjukan bahwa proporsi WUS yang memiliki LiLA < 23,5 $\mathrm{cm}$ lebih rendah yaitu 27,8\% dibandingkan dengan proporsi WUS yang memiliki LiLA $\geq$ $23,5 \mathrm{~cm}$ yaitu sebesar $72,2 \%$. Selain itu penelitian ini juga sejalan dengan penelitian Muslimah (2017) yang menyatakan proporsi WUS yang memiliki LiLA < 23,5 cm lebih rendah yaitu $25 \%$ dibandingkan dengan proporsi WUS yang memiliki LiLA $\geq 23,5$ yaitu $75 \%$.

Dampak jangka panjang dari masalah gizi pada WUS yang mengalami KEK adalah mempunyai risiko yang lebih besar untuk melahirkan bayi dengan BBLR. KEK pada wanita apabila tidak tertangani dengan baik dapat berkelanjutan saat hamil, yaitu selain dapat melahirkan bayi BBLR, juga akan membawa risiko kematian (Sofiyani, 2017). Untuk menanggulangi resiko melahirkan BBLR, sebelum kehamilan WUS sudah harus mempunyai gizi yang baik, misalnya dengan LiLA tidak kurang dari $23,5 \mathrm{~cm}$. Apabila LiLA WUS sebelum hamil kurang dari angka ini, sebaiknya kehamilan ditunda sehingga tidak beresiko melahirkan BBLR (Adriani \& Wirjatmadi, 2012). Oleh karena itu resiko KEK pada Mahasiswi FIKes UIKA perlu mendapatkan perhatian.

\section{Gambaran BB}

Berat badan merupakan ukuran antropometris yang paling banyak digunakan karena parameter ini mudah dimengerti sekalipun oleh mereka yang buta huruf. Agar berat dapat dijadikan satu ukuran yang valid, parameter lain seperti tinggi, ukuran rangka, proporsi lemak, otot, tulang, serta komponen "berat patologis" (misalnya edema, 
splenommegali) harus dipertimbangkan. Dengan kata lain, ukuran berat harus dikombinasikan dengan parameter antropometris yang lain (Arisman, 2009).

Berdasarkan hasil penelitian menunjukan bahwa rata-rata berat badan mahasiswi FIKes UIKA adalah $52,93 \mathrm{~kg}$ dengan nilai tengah $51,9 \mathrm{~kg}$. Berat Badan terendah berada pada $34,9 \mathrm{~kg}$, sedangkan berat badan terbesar ialah $92,5 \mathrm{~kg}$.

Hasil penelitian yang dilakukan oleh Sofiyani (2017) pada Santriwati di Pondok Pesantren Al-Islam Yogyakarta menunjukan bahwa berat badan responden di Pondok Pesantren Al-Islam paling rendah adalah 32 $\mathrm{kg}$ dan berat badan tertinggi adalah $71 \mathrm{~kg}$, sedangkan untuk rata-rata berat badan responden sendiri menunjukan hasil yang tidak jauh berbeda dengan penelitian yang dilakukan pada mahasiswi FIKes UIKA yaitu $51,28 \mathrm{~kg}$.

Berat badan lebih disebabkan oleh ketidakseimbangan antara konsumsi energi dengan kebutuhannya. Konsumsi energi berlebihan disimpan dalam bentuk jaringan lemak. Pada keadaan normal jaringan lemak ditimbun didalam jaringan subkutan dan jaringan tirai usus (omentum). Pada wanita disimpan ditempat khusus dan memberi bentuk feminin seperti pada bahu, dada, panggul, dan pantat. Salah satu parameter yang digunakan untuk menentukan seseorang dewasa memiliki berat badan lebih atau tidak yaitu dengan menggunakan ukuran IMT. (Departemen Gizi dan Kesehatan Masyarakat, 2010).

\section{Gambaran TB}

Tinggi atau panjang badan merupakan indikator umum ukuran tubuh dan panjang tulang. Namun, tinggi saja belum dapat dijadikan indikator untuk menilai status gizi, kecuali jika digabungkan dengan indikator lain, seperti usia dan berat badan (Arisman, 2009). Pengukuran tinggi badan seseorang pada prinsipnya adalah mengukur jaringan tulang skeletal yang terdiri dari kaki, panggul, tulang belakang, dan tulang tengkorak. Penilaian status gizi pada umunya hanya mengukur total tinggi (atau panjang) yang diukur secara rutin. Tinggi badan yang dihubungkan dengan umur dapat digunakan sebagai indikator status gizi masa lalu (Deparetemen Gizi dan Kesehatan Masyarakat FKM UI, 2010)

Berdasarkan hasil penelitian menunjukan bahwa rata - rata mahasiswi FIKes UIKA memiliki tinggi badan 154,27 $\mathrm{cm}$ dengan nilai tengah $154 \mathrm{~cm}$. Mahasiswi dengan ukuran terendah memiliki tinggi badan $143 \mathrm{~cm}$ dan mahasiswi dengan ukuran tertinggi memiliki tinggi badan $167 \mathrm{~cm}$.

Hasil penelitian yang dilakukan oleh Handayani (2016) menunjukan bahwa sebagian responden memiliki tinggi badan normal $91,2 \%$ dengan rata-rata tinggi badan $157,27 \mathrm{~cm}$ dan hanya sebagian kecil yang memiliki tinggi badan pendek 8,8\% dengan rata-rata tinggi badan $147,94 \mathrm{~cm}$. Penelitian serupa yang pernah dilakukan oleh Sambeka, Tanudjaja dan Pasiak (2015) juga menunjukan hasil yang tidak jauh berbeda dengan penelitian yang dilakukan Handayani (2016) yaitu responden memiliki rata-rata tinggi badan $158,0 \mathrm{~cm}$.

Pertumbuhan tinggi badan dipengaruhi oleh dua faktor utama yaitu faktor genetik dan faktor lingkungan. Faktor genetik yang mempengaruhi tinggi badan anak seperti faktor umur, dimana pertumbuhan tinggi badan akan berbeda pada setiap tahapan pertumbuhan. Tinggi badan pada masa remaja berhubungan erat dengan terjadinya pertumbuhan pubertas pertama dan menarche, dimana puncak pacu tumbuh tinggi badan terjadi diantara kedua waktu tersebut. Tinggi badan dipengaruhi pula oleh faktor keluarga, jenis kelamin, perbedaan ras/etnik/suku bangsa, kelainan kromosom, dan kelainan genetik. Selain faktor genetik, pertumbuhan tinggi badan dipengaruhi pula oleh faktor lingkungan yang terdiri dari lingkungan perinatal, saat persalinan, dan lingkungan 
pascanatal. Termasuk lingkungan pascanatal yang mempengaruhi tinggi badan anak antara lain; nutrisi, penyakit kronis, penyakit endokrin, penyakit sistemik, hormon, kecelakaan, lingkungan fisik/sanitasi, lingkungan pengasuhan, psikologis, stimulasi, media, pekerjaan orang tua, jumlah saudara, dan pendidikan terakhir orang tua (Soetjiningsih, 2015 dalam Handayani, 2016).

\section{Gambaran IMT}

Indeks Massa Tubuh (IMT) merupakan alat sederhana untuk memantau status gizi orang dewasa khususnya yang berkaitan dengan kekurangan dan kelebihan berat badan. Penggunaan IMT hanya berlaku untuk orang dewasa berumur diatas 18 tahun, IMT tidak dapat diterapkan pada bayi, anak, ibu hamil dan pada keadaan khusus lainnya seperti edema, asites, dan hepatomegaly (Adriani \& Wirjatmadi, 2012).

Berdasarkan hasil penelitian menunjukan jumlah IMT bahwa IMT kurus sebesar 20,6\%, IMT normal sebesar 56,1\%, IMT gemuk sebesar 13,1 dan IMT obesitas sebesar 10,3\%. Data yang di dapatkan berdasarkan hasil penelitian, dapat diketahui bahwa IMT terbanyak yaitu IMT normal dengan $56,1 \%$.

Hasil penelitian ini sejalan dengan hasil penelitian yang dilakukan oleh Jannah, Bebasari dan Ernalia (2015) yang menunjukan bahwa proporsi WUS yang memiliki IMT kurus lebih rendah yaitu 10,9\% dibandingkan dengan proporsi WUS yang memiliki IMT normal yaitu sebesar 49,2\%. Selain itu penelitian ini juga sejalan dengan penelitian Zuhairini, Kasmanto dan Nugraha (2016) yang menyatakan bahwa proporsi WUS yang memiliki IMT kurus 7,38\% lebih rendah dibandingkan dengan proporsi WUS yang memiliki IMT normal yaitu sebesar $15,27 \%$.

Dalam hal gizi kurang terjadi ketidakseimbangan negatif, yaitu asupan lebih sedikit dari kebutuhan. Secara umum, kekurangan gizi menyebabkan beberapa gangguan dalam proses pertumbuhan, mengurangi produktivitas kerja dan kemampuan berkonsentrasi, struktur dan fungsi otak, pertahanan tubuh, serta perilaku (Almatsier, 2009).

Dalam hal obesitas, penderita obesitas mempunyai status nutrisi yang melebihi kebutuhan metabolisme karena kelebihan masukan kalori atau penurunan penggunaan kalori, artinya masukan kalori tidak seimbang dengan penggunaannya yang pada akhirnya berangsur-angsur berakumulasi meningkatkan berat badan (Adriani \& Wirjatmadi, 2012). Obesitas itu sendiri merupakan salah satu faktor resiko penyakit degeneratif, seperti penyakit kardiovaskuler, hipertensi, dan diabetes mellitus (Arisman, 2009).

\section{Proporsi Antara Umur Dengan KEK}

Berdasarkan hasil penelitian menunjukan bahwa mahasiswi yang mengalami KEK berada pada umur 18 sampai 22 tahun, mahasiswi yang mengalami KEK lebih banyak berada pada umur 19 tahun, yaitu 8 mahasisiswi.

Penelitian yang dilakukan oleh Rahayu (2017) menunjukan bahwa secara statistik terdapat hubungan yang signifikan antara umur dengan KEK. Nilai OR = 3,14. Berbeda dengan penelitian yang dilakukan oleh Handayani dan Husna (2014) yang menunjukan bahwa nilai $\mathrm{p}=0,237$, hal ini menunjukan bahwa tidak ada pengaruh antara umur terhadap kejadian KEK.

\section{Proporsi Antara IMT Dengan KEK}

Menurut (Stratton et al., 2004) LiLA < $23,5 \mathrm{~cm}$ terkait dengan nilai IMT $<20 \mathrm{~kg} / \mathrm{m} 2$, dengan hasil tersebut dapat diketahui bahwasannya subjek berada dalam keadaan berisiko malnutrisi. Penelitian ini juga membahas penurunan berat badan seiring dengan berjalannya waktu dan nilai LiLA. Dalam hal ini diperkirakan bahwa jika LiLA mengalami perubahan paling sedikit 10\%, BB dan IMT mungkin juga akan berubah sebesar $10 \%$ atau lebih (Stratton et al., 2004)

Berdasarkan hasil penelitian 
menunjukan bahwa mahasiswi yang memiliki status gizi kurus, lebih besar berpeluang mengalami KEK yaitu 17,8\% dibandingkan dengan mahasiswi yang status gizinya normal mengalami KEK yaitu 5,6\%.

Penelitian yang dilakukan oleh Octaviani (2017) menunjukan bahwa LiLA pada WUS memiliki nilai $(\mathrm{r}=0,998$ dan $\mathrm{p}=$ 0,002). Hal ini menunjukan bahwa hubungan antara LiLA dengan status gizi secara statistik bermakna karena nilai $\mathrm{p}<0,05$.

\section{Kesimpulan}

Berdasarkan hasil penelitian mengenai Gambaran Status Gizi Berdasarkan Lingkar Lengan Atas dan Indeks Massa Tubuh Pada Mahasiswi FIKes UIKA Bogor Tahun 2019, maka kesimpulan yang dapat peneliti sampaikan adalah Mahasiswi FIKes UIKA yang rata-rata berumur 20 tahun mengalami KEK sebesar 23,4\%. Mahasiswi FIKes UIKA yang memiliki IMT kategori normal sebanyak $56,1 \%$, namun status gizi berat badan lebih cukup banyak 23,4\% dibandingkan dengan status gizi kurus 20,6\%. Mahasiswi FIKes UIKA yang
Berdasarkan rencana strategis program Direktorat Jenderal Bina Gizi dan KIA (2015 - 2019) memiliki luaran yaitu menurunnya jumlah WUS KEK. Indikator pencapaian luaran tersebut pada tahun 2019 adalah jumlah WUS dengan LiLA $<23,5 \mathrm{~cm}$ maksimal $18,2 \%$, sedangkan pada penelitian yang dilakukan oleh peneliti di FIKes UIKA menunjukan bahwa mahasiswi yang mengalami KEK mencapai 23,4\%.

memiliki status gizi kurus, lebih besar berpeluang mengalami KEK yaitu 17,8\% dibandingkan dengan mahasiswi yang status gizinya normal mengalami KEK yaitu 5,6\%.

Saran ditujukan kepada Fakultas Kesehatan Masyarakat Universitas Ibn Khaldun, diharapkan menerapkan deteksi status gizi secara berkala kepada seluruh mahasiswa untuk mencegah timbulnya masalah gizi. Selain itu, perlu dilakukan health promotion pada mahasiswa terkait cara pencegahan dan penanganan KEK, obesitas dan status gizi kurus. 


\section{Daftar Pustaka}

[1] Abaa, Y. P., Polii, H., \& Wowor, P. M. (2017). Gambaran Tekanan Darah, Indeks Massa Tubuh, dan Aktifitas Fisik pada Mahasiswa Kedokteran Umum Angkatan Tahun 2014. e-

Biomedik (eBm), Volume 5 Nomor 2. https://ejournal.unsrat.ac.id/index.php/e biomedik/article/view/18509 diakses pada 11 Maret 2019

[2] Adriani, M., \& Wirjatmadi, B. (2012). Peranan Gizi Dalam Siklus Kehidupan. Jakarta: Kencana.

[3] Almatsier, S. (2009). Prinsip Dasar Ilmu Gizi. Jakarta: PT Gramedia Pustaka Utama.

[4] Arisman. (2009). Buku Ajar Ilmu Gizi Dalam Daur Kehidupan. Jakarta: ECG.

[5] Arisman. (2004). Gizi Dalam Daur Kehidupan. Jakarta: ECG Kedokteran.

[6] Departemen Gizi dan Kesehatan Masyarakat. (2010). Gizi dan Kesehatan Masyarakat. Jakarta: RajaGrafindo Persada

[7] Departemen Kesehatan RI. (2001). Pedoman Praktis Pemantauan Status Gizi Orang Dewasa. Depkes RI

[8] Dinas Kesehatan. (2016). Profil Kesehatan Provinsi Jawa Barat. Dinas Kesehatan Provinsi Jawa Barat. http://www.depkes.go.id/resources/dow nload/profil/PROFIL_KES_PROVINSI 2016/12_Jabar_2016.pdf diakses pada 30 Januari 2019

[9] Handayani, R. (2016). Gambaran Tinggi Badan Mahasiswa S1 Pendidikan Bidan Universitas Airlangga berdasarkan Faktor yang Mempengaruhinya. Universitas Airlangga.repository.unair.ac.id/54139/ 25/ABSTR AK-min.pdf diakses pada 16 Februari 2019

[10] Handayani, S., \& Husna, P. H. (2014). Faktor yang mempengaruhi Kejadian Kurang Energi Kronis Pada Ibu Hamil.
Akademi Keperawatan Giri Satria Husada Wonogiri. journal.akpergshwng.ac.id/index.php/gs h/article/view/ diakses pada 18 Februari 2019

[11] Jannah, W., Bebasari, E., \& Ernalia, Y. (2015). Profil Status Gizi Mahasiswa Fakultas Kedokteran Universitas Riau Angkatan 2012 dan 2013 Berdasarkan Indeks Massa Tubuh, Waist Hip Ratio dan Lingkar Pinggang. Universitas Riau.

https://jom.unri.ac.id/index.php/JOMFD OK/article/view/4187 diakses pada 16 Februari 2019

[12] Mahirawati, V. K. (2014). Faktor-faktor yang berhubungan dengan kekurangan energi kronik (KEK) pada ibu hamil di Kecamatan Kamoning dan Tambelangan, Kabupaten Sampang, Jawa Timur. Jurnal Kesehatan Vol 17 No.2.

https://media.neliti.com/media/publicati ons/20898-ID-related-factors-ofchronic-energy-deficiency-at-pregnantwoman-in-kamoning-and-t.pdf diakses pada 30 Januari 2019

[13] Muslimah, A. R. (2017). Hubungan Indeks Massa Tubuh dengan Lingkar Lengan Atas pada Ibu Hamil Trimester 1 di Puskesmas Umbulraharjo 1 Kota Yogyakarta Tahun 2016. Universitas Aisyiyah Yogyakarta. http://digilib.unisayogya.ac.id/2649/1/na skah\%20publikasi.pdf diakses pada 29 Januari 2019

[14] Octaviani, S. (2017). Hubungan Indeks Massa Tubuh dan Lingkar Lengan Atas, Lingkar Pinggang, dan Lingkar Panggul dan Status Gizi Mahasiswa FK USU. Universitas Sumatera Utara. http://repositori.usu.ac.id/handle/123456 789/4889 diakses pada 19 Januari 2019

[15] Pemantauan Status Gizi. (2017). Buku 
Saku Pemantauan Status Gizi Tahun 2017. Kemenkes RI. http://www.kesmas.kemkes.go.id/assets /upload/dir_519d41d8cd98f00/files/Buk u-Saku-Nasional-PSG-2017_975.pdf diakses pada 19 Januari 2019

[16] Puli, T., Thaha, R. R., \& Syam, A. (2014). Hubungan Sosial Ekonomi dengan Kekurangan Energi Kronik (KEK) pada Wanita Prakonsepsi di Kota Makasar. Universitas Hasanuddin. https://core.ac.uk/download/pdf/254966 66.pdf diakses pada 5 Februari 2019

[17] Putri. (2016). Asupan Makan terhadap Kadar Trigliserida pada Mahasiswa Obesitas di Fakultas Kedokteran Universitas Lampung Universitas Lampung.http://repository.lppm.unila.a c.id/10100/1/agro_des2017_septyne_dia n_betta.pdf diakses pada 30 Januari 2019

[18] Rahayu, I. P. (2017). Hubungan Umur dan Graviditas dengan Kejadian Kurang Energi kronik (KEK) pada Ibu Hamil di Puskesmas Lepo - Lepo Kota Kendari Provinsi Sulawesi tenggara Tahun 2016. Kendari: Politeknik Kesehatan Kendari. http://repository.poltekkes-

kdi.ac.id/429/1/SKRIPSI\%20IKA\%20P UTRI\%20RAHAYU.pdf diakses pada 5 Februari 2019

[19] Riskesdas. (2018). Hasil Utama Riskesdas 2018. Kemenkes RI. http://www.depkes.go.id/resources/dow nload/info-

terkini/materirakorpop2018/Hasil\%20

Riskesdas\%202018.pdf diakses pada 30 Januari 2019

[20] Sambeka, C., Tanudjaja, G. N., \& Pasiak, T. F. (2015). Hubungan Tinggi Badan Dengan Panjang Tangan Pada Mahasiswa Fakultas Kedokteran Unsrat Angkatan 2013. Jurnal e-Biomedik
(eBm), Volume 3 Nomor 1, h 310 315.https://ejournal.unsrat.ac.id/index.p hp/ebiomedik/article/view/7126.diakses pada 9 Maret 2019

[21] Sofiyani, F. A. (2017). Gambaran Status Gizi Remaja Berdasarkan Indeks Massa Tubuh dan Lingkar Lengan Atas di Pondok Pesantren Al - Islam Kota Yogyakarta Tahun 2017. Yogyakarta: STIK Jenderal Ahmad Yani. http://repository.unjaya.ac.id/2345/2/FI VI\%20ARNIA\%20SOFIANI\%20\%281 114052\%29nonfull.pdf diakses pada 5 Februari 2019

[22] Stratton, R. J.,Hackson, A., Longmore, D., Dixon, R., Price, S., Stroud, M., et al. (2004). Malnutrition in hospital outpatients and inpatients: prevalence, concurrent validity and ease of use of the malnutrition universal screening tool (MUST) for adults. Br J Nutr, vol. 92,pp.799 808. https://doi.org/10.1079/BJN20041258 diakses pada 30 Maret 2019

[23] World Health Organization. (2012). Maternal Mortality. http://www.who.int/mediacentre/facshe e ts/fs348/en/ diakses pada 11 Maret 2019

[24] Zuhairini, Y.,Kasmanto, H.,\& Nugraha, G. I. (2016). Indeks Massa Tubuh Awal Kehamilan Ibu Sebagai Indikator yang Paling Berperan Terhadap Kenaikan Berat Badan Ibu Selama Hamil. Jurnal MKB, Volume 48 No 3, halaman 171 175.https://www.researchgate.net/public ation/308945935_Indeks_Massa_Tubuh _Awal_Kehamilan_Ibu_sebagai_Indika tor_yang_Paling_Berperan_terhadap_K enaikan_Berat_Badan_Ibu_Selama_Ha mildiakses pada 9 Maret 2019 diakses pada 9 Maret 2019 